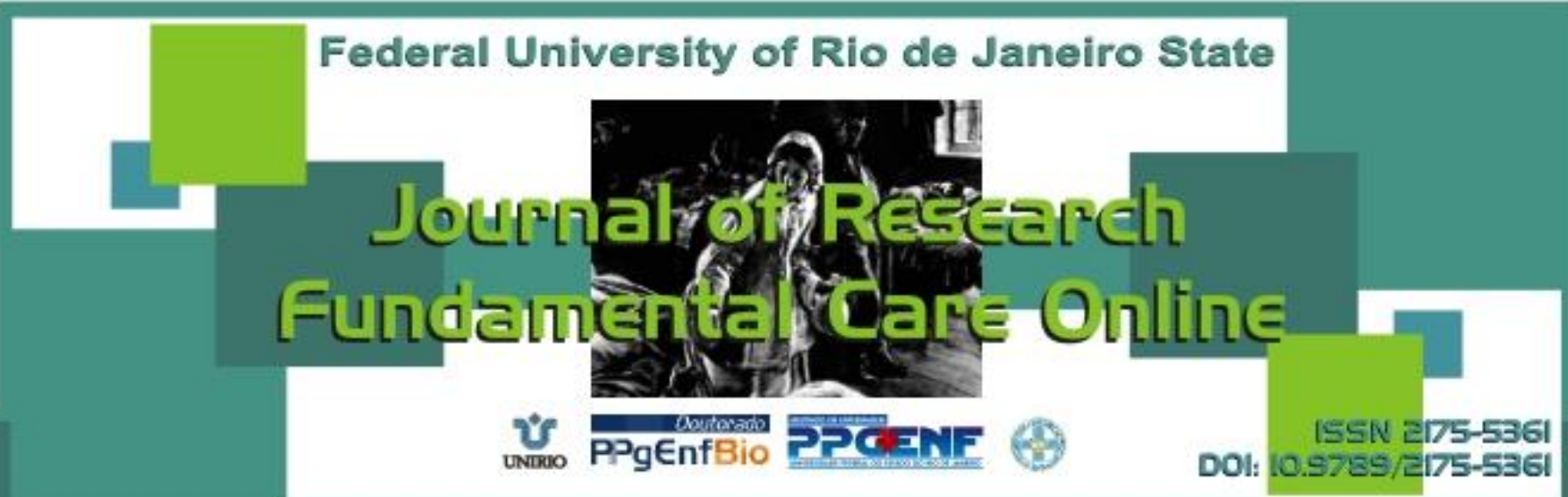

\title{
RESEARCH
}

\section{Clinical care nursing in mental health: reflections on a practice nurse}

Cuidado clínico de enfermagem em saúde mental: reflexões sobre a prática do enfermeiro

Cuidados de enfermería clínica en salud mental: reflexiones sobre una enfermera practica

Arisa Nara Saldanha de Almeida ${ }^{1}$, Rúbia Mara Maia Feitosa ${ }^{2}$, Emilie Fonteles Boesmans ${ }^{3}$, Lia Carneiro Silveira ${ }^{4}$

ABSTRACT

Objective: Understand how clinical care in nursing can develop into a perspective that considers the person in distress as subject of this practice. Method: Work result of workshop with 17 nurses who work in the day-care Center of Fortaleza. Results: Through analysis of the lines of the nurses at the workshop, we come to the elaboration of the following categories: that subject matter. Subject and listening for who cares. The workshop allowed the nurses approach of other theoretical and methodological references to conceptualize the subject beyond Cartesian as, for example, the reference of psychoanalysis, allowing the nurse recognizes that the process of care is complex and demand actions based on the uniqueness of each subject. Conclusion: psychoanalysis emerges as a theoretical tool that can contribute to the nurse in this endeavor as it constructs a listening space, whose knowledge is supposed to be the person who speaks. Descriptors: Nursing, Mental health, Psychoanalysis.

\begin{abstract}
RESUMO
Objetivo: Compreender como o cuidado clínico em enfermagem pode ser desenvolvido em uma perspectiva que considere a pessoa em sofrimento psíquico como sujeito dessa prática. Método: Trabalho resultado da oficina com 17 enfermeiros que atuam no Centro de Atenção Psicossocial de Fortaleza/CE. Resultados: Mediante análise das falas dos enfermeiros na oficina, chegamos à elaboração das seguintes categorias: De que sujeito se trata? Sujeito e Escuta e a Escuta de quem cuida. A oficina permitiu que os enfermeiros se aproximassem de outros referenciais teóricos e metodológicos que conceituam o sujeito para além do cartesiano como, por exemplo, o referencial da psicanálise, possibilitando que o enfermeiro reconheça que o processo de cuidar é complexo e demanda ações pautadas na singularidade de cada sujeito. Conclusão: A psicanálise surge como ferramenta teórica que pode contribuir com o enfermeiro nessa empreitada, pois constrói um espaço de escuta, cujo saber é suposto ao sujeito que fala. Descritores: Enfermagem, Saúde mental, Psicanálise.
\end{abstract}

\section{RESUMEN}

Objetivo: Comprender cómo clínico cuidados en enfermería puede ser convertido en una perspectiva que considera a la persona en apuros como sujeto de esta práctica. Método: Trabajo resultado del taller con 17 enfermeras que trabajan en el centro de cuidado diurno de Fortaleza. Resultados: A través del análisis de las líneas de las enfermeras en el taller, llegamos a la elaboración de las siguientes categorías: ese tema? Tema y escuchando y escuchando a quién le importa. El taller permitió las enfermeras enfoque de otras referencias teóricas y metodológicas para conceptualizar el tema más allá de cartesiano como, por ejemplo, la referencia del psicoanálisis, permitiendo la enfermera reconoce que el proceso de cuidado es complejo y las acciones de demanda basan en la singularidad de cada sujeto. Conclusión: Psicoanálisis emerge como una herramienta teórica que puede contribuir a la enfermera en este esfuerzo como construye un espacio de escuchando, cuyo conocimiento se supone que quien habla. Descriptores: Enfermería, Salud mental, Psicoanálisis.

${ }^{1}$ Nurse. Master in Clinical Care in nursing and Health by the Universidade Estadual do Ceará-UECE. Email: arisanara@gmail.com. ${ }^{2}$ Nurse. Master in Clinical Care in nursing and Health by the Universidade Estadual do Ceará-UECE. arisanara@gmail.com. ${ }^{2}$ Nurse. Master in Clinical Care in nursing and Health by the Universidade Estadual do Ceara-UECE.
Email: rubinhafeitosa@hotmail.com. ${ }^{3}$ Psychologist. Master's degree in psychology from the Federal University of Ceará-UFC. Email: emilieboesmans@hotmail.com. ${ }^{4}$ Nurse. Psychoanalyst of the Lacanian Field Forum in Fortaleza-Ceará. Faculty of the Graduate program in nursing and Clinical Health Care of the Universidade Estadual do Ceará (UECE/PPCCLIS). E-mail: silveiralia@gmail.com. 


\section{INTRODUCTION}

hat I am? What I can think of? Of course, nowadays, we encounter doing such questions at some point in our lives. The content of these two questions have led Descartes (1596-1650) to formulate for the first time in the history of ideas the concept of subject. It was from his work entitled the Speech method $(1637 / 2001)$ which sought to explain a way to search for the truth through a method: philosophical and mathematician. We realize that is only true for Descartes, anything that can conceived in a clear and objective manner, so only the reason is able to drive the man to this process. Thus, the subject that will formulated by the Cartesian method is none other than the subject of science. ${ }^{1}$

The equation "I think, therefore I am" is the only truth of which we cannot doubt. When switching on the existence of the subject to know the Act of thinking, Descartes to dissociate from everything that not tied to the reason: "I'm not but a thing that thinks." Thus, the definition of this subject is something whose substance is the thought. Therefore, to arrive at a conclusion about who I am, Descartes rejects the senses, because for him these are always misleading. Thereby, the subjectivity leads to the removal of the rational ideas. So, what we see, feel, that you feel is not able to say who I am in this perspective, claims that the scientific discourse separates the existence and attributes of the subject itself, that separation becomes an ideal for modern science. A thought without qualities, whose correspondent is a man without qualities, too ${ }^{2}$.

For being, a substantial subject considered fully aware of his actions. This is still a perception that guides the practices of nurses in the care of patients with distress that, conditioned by the prescriptive actions, have a character clearly adaptive and goal, a centralized clinic in giving "corrective" measures like the hygienic and feeding, behavior patterns, uses of drugs that, supposedly, placate pain and makeup on symptoms with antianxiety drugs or antidepressants. ${ }^{3}$

The first major break with the notion of subject established by modern science, by the Cartesian thought occurred from Freudian discourse. Freud, to discover the unconscious, contributed to the deconstruction of the concept of subject anchored in rationality. In Freudian theory, the subject is a subject split, is a subject marked by a hiatus. Is a person who, while saying, "I think", is subordinate to another scene, another place besides him-the unconscious. $^{4}$

Currently for realization of clinical nursing care, practices in mental health have Psychosocial Attention centers (CAPS). These configured in an open and community health service that serves as a reference for treating people with psychic suffering. In this environment, these nurses must apply their clinical care while encountering subject in distress. 
The objective of this work is to understand how clinical care in nursing can developed into a perspective that considers the person in distress as subject of this practice. However, we can ask ourselves, what subject are we referring? I wonder if it comes to the Cartesian individual, taken in its full length of body. Still in its rationality? We developed this study in order to reflect the possibilities of clinical nursing care in mental health from the theoretical framework of psychoanalysis.

The work becomes relevant by allowing nurses an opportunity to rethink their practice, going beyond the traditional health care model based on listener that assumes a Cartesian subject, fully aware of the reasons of their suffering. Can collaborate to instigate the curiosity of nurses to address other methodological theoretical references.

\section{DESIGN of SUBJECT in CLINICAL CARE in MENTAL HEALTH}

The clinic of the subject based on a benchmark of psychoanalysis seeks to put its emphasis on the subject. ${ }^{5}$ and this matter be able to transmit a knowledge unknown to other speeches, which marked by the unconscious. Thereby, excluded from the medical discourse, subjectivity privileged in psychoanalytic discourse, allowing understanding the possibility of articulation between symptoms, and how the subject means the events of your life. It is from the talks is that you can have access to psychic reality, discursive position of the subject.

Lacan when writing the text "Science and the truth" mentions that psychoanalysis operates on this same subject of science. It seems paradoxical at first, but later you will realize that the emergence of psychoanalysis is historically dependent on scientific thinking ${ }^{6}$. What can be rescued from the considerations of Lacan is that the importance of the cogito for psychoanalysis in virtue of the subject's relationship with its symbolic aspect. It is through this dimension that something can have value of existence to be ${ }^{5}$ speaker.

Thus for psychoanalysis the subject is also the subject of unconscious thought. However, is no refer to the psychic dimension that this subject cannot manifest. The subject unconscious structured in the form of language. Therefore, the subject is conscious of the subject of unreason refers the reason unconscious whose logic is also seized through a method, not the Cartesian method, but to what is called a psychoanalytic method ${ }^{1}$.

Psychoanalysis thus based from its own principles and methods. That is the great contribution of psychoanalysis: configured in a speech, brings the particular of the other speeches, the other to whom it addressed is, par excellence, the subject itself. ${ }^{7}$

Thus, if the Cartesian procedure and the Freudian converge in defining the subject by reason, differ in relation to the substance: for Descartes the subject is a thinking thing, while for psychoanalysis subject has no substance, manifesting in hesitation, when in doubt between this and that. "The unconscious is the chapter of my story that is marked by a white or occupied by a lie: it is the censored chapter". 8: 260 otherwise, the subject for psychoanalysis is that memory erased, this missing signifier, that void of representation in which manifests the desire. ${ }^{1}$

Therefore, the cogito Freudian is first foremost "desidero ergo sum" (I wish I am soon), a time where there is desire, is the subject with effect of Association of representations. 
Desire is the name of the subject of the Freudian era. In this way, the subject that psychoanalysis discovers in the rubble of the pathology is a subject that is fundamentally desire. $^{2}$

The subject unconscious is able to transmit a knowledge unknown to himself. However, it is not always this person wants to know what struggle so much to protect. Although it is a censored chapter, the truth can rescued, because in large part, she has written otherwise, with other contours, with other colors and elsewhere. A writing containing texts whose parts of phrases can be suppressed, meaningless. Therefore, it is not because he does not want to know that it does not manifest itself. Nevertheless, in what way? The subject unconscious reveals itself in the speech of one who seeks to understand the meaning of your pain, your anguish. ${ }^{8}$

In this perspective, to reveal himself by talking about the subject unconscious structured in language. Therefore, something beyond the control of the subject, something that is not conscious and that it does not belong. Moreover, it is through language that the subject unconscious leaves traces of its visibility. ${ }^{9}$

The unconscious can accessed by their effects in dreams, in lapses, in acts and jokes on us, flawed symptom. That is the way he dribbles the armor and censor strategies of psyches, it misses the truth of the subject. In addition, as Quinet ${ }^{1}$, the meaning of them, in fact, constitutes the desire, so elusive, as the subject itself that there is manifest.

Therefore, in this clinic, the subject is one who speaks and relates to others in the same position in socio-historical reality. In contrast to the classical psychology, founded in Descartes and materialized in the practices of interpretation, this new reference puts the subject in the field of otherness and its impasses. ${ }^{10}$ Therefore, is through the understanding of speech and language that are inserted in a field of immanent forces to the body, to your satisfaction goals/repulsion and others, it is possible to develop a doubly active therapeutic relationship, in which the subject has autonomy to act before new configurations arising from his sayings.

Persists between us a meaning of care linked to the transmission of knowledge and information, pervaded by a bias behavior source that aims at changing attitudes of subjectsworkers. In which the nurse assumes the role of emitter while the patient intended for the role of receiver. Preexisting assignments, making the production of subjective encounters and strengthening care actions, prescriptive modeling highly geared to behavior change and taking the patient in the abstract. ${ }^{11}$

This perspective of the process of nursing care, in its one-sided version and skilful, engages the notion of hegemonic still, as individual process of body protection, health, regardless of historical, cultural, social conditions, economic and natural of the subject. The caution, as lonely and individual act, it becomes more a way to blame the patients for what occurs in their lives.

In this sense, the procedure relating to mental health eventually reduced to an act of Protocol, a technique of evidence collection, of signs, or the interpretive game. To listen deaf performed by nurse's produces the effect of protection of subject, since it speaks for, say, on behalf of, in place of talking with each other. So, what kind of listening want to take patients in distress as subjects of their life processes, suffering? 
We understand that you cannot deploy a form of service that go against the biomedical model of assistance, going so far as to deny and/or devalue the contributions that know the field of mental health. If not found it, but it is important that the nurse working in the center of psychosocial care (CAPS), recognize the patient in distress while subject of singular existence, considering its subjective position.

In this way, we realize that nursing care can take as a field based on interventions that go beyond the instrumental character and filling in forms to obtain clinical information on the disease. However, get a caution, based on other benchmarks; you can appreciate the suffering of the patient in distress. With the prospect of doing a clinical nursing care to visualize in the clinical term care actions beyond diagnosis, signs and symptoms.

We emphasize that the concept of Clinical Care is being built by the Faculty and students of the Master's program in Clinical Care in nursing and Health at the State University of Ceará in prospect of producing new knowledge and practices in the field of health, breaking with the biomedical paradigm. In the line of research on which this text inserted, it is an articulation of the concept of care (while the subject's Constitution process in their conditions of access to the truth) with the concept of clinic (taken in its etymological root Klinikê, which means lean, lean to hear a subject). Clinical care, in this perspective, is a conceptual field where the clinical intervention only be mediated by listening for a person what he establishes from relations with his own truth.

Thus, $\mathrm{as}^{3}$ Almeida addresses need to assume a new posture based on ethical dimension. Moreover, it impels the nurse also shift his place. While the traditional model requested to occupy the place of the expert, developed in the clinic of the subject it must leave this place of knowing preset. Therefore, it is essential that you listen to open space for the subject to draw up the specifics of your situation, of your suffering. "The exercise of clinic in speech acts, listens, in which the diagnosis wins the dimension of care. ${ }^{12: 127}$

This procedure relating to mental health involves putting the subject in active position and directly responsible for its position and enjoyment. To be part of a process of psychic suffering, the subject must be the target of a wiretap alive, where there is the preparation of a speech in which evidenced significant and, from these, produce new meanings.

So, put the subject in focus, active, means performing nursing care from a clinic of the subject, involves conceiving him differently, i.e. it is blame him, inviting him to occupy a different position of the object of desire of Another. ${ }^{13}$ thus, for carrying out clinical nursing care vis-à-vis the subject's clinic, the nurse must occupy a new place, not the other holder of knowledge, but the one that comes with the subject in the discovery of what constitutes his desire, i.e. enable you to say or to seize what meanings emerge from the combination between the signifiers. Therefore, the nurse should not appoint the desire, but to foster conditions for the subject contact the desire to decipher it. ${ }^{14}$ but for that to happen, it is essential that the professional learn direct so evoked listen.

Listening means evoke the client speaks, what he says and why it says. The listener process only has meaning because it allows you to count and count yourself. That necessarily need to go through the other, i.e. it takes always another to say. If the other is not there, there is an absence. So the "listening to you" passes by the fact of being listened to by the other. ${ }^{15}$ For a broader understanding of the mechanisms of listening, we need to consider a fundamental point, the language. Freud investigated the joints between the 
representations and the body, and, in his psychoanalytic adventure, not measured efforts scientifically clarify the magical power of words.

The nonprofessional of course find difficult to comprehend that the pathological disturbances of body and soul can eliminated through "mere" words. You will find that you are asking me to believe in witchcraft. In addition, do not be so wrong: the words of our everyday speech is just magic more strongly attenuated. However, you will need to take a roundabout path to make understandable how science employed to restore the words at least part of his old magical power. ${ }^{(16: 283)}$

In the psychoanalytic clinic, what matters is the reality of the subject, not the reality itself. In this perspective, the procedure relating to mental health becomes a strategy for the development of clinical nursing care, focusing on accountability in the process of the subject as it clarifies that each possesses in itself the answers to their problems.

We realize that the nurses who work in CAPS might be more sensitive to content production from the talks about the subject, promoting clinical care more committed to the development of life.

\section{METHODOLOGY}

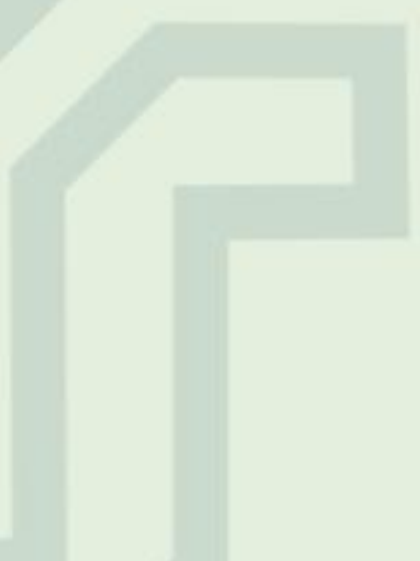

This research has a qualitative approach, because it allows discover social processes still little known, but also reflect and build new concepts from the object of study. Have theoretical Fundação, in addition to promote the systematization of empirical knowledge to the understanding of the internal logic of the group or of the process under study. ${ }^{17}$

The research emerged from the pilot survey entitled "Nursing Care in mental health: the contribution of the subject's clinic" developed by the Clinical Laboratory of the subject of the Universidade Estadual do Ceará (UECE/LACSU) through the Academic master program Clinical Care in nursing and health (PMACCLIS), by undergraduate and graduate students in nursing and teachers aimed at nurses that work in the day-care Center of the municipality of Fortaleza/Ceará interested in study, reflection and modification of nursing practice in the context of mental health. Told with the participation of 17 nurses.

For the development of the work held four pilot workshops throughout the year of 2010, with research participants. In this work, we stop us on the data resulting from the third workshop that focused on the discussion of the conception of subject and its articulation with the clinical nursing care to patients in distress. Participated in that moment 12 people between nurses, undergraduate students and nurses who work in daycare Centers.

The workshop began with an activity of awareness from sensory stimulation technique where, barefoot and blindfolded, the participants were experiencing objects with 
different textures, colors and thermal sensations that offered by the coordinators. Then participants performed the reading and discussion of the text entitled "Subjectivity at work with Mental Health". ${ }^{18}$ after reading opened a debate on the guiding question: as clinical nursing care can be developed into a perspective that considers the person in distress as subject of this practice?

The information produced in this research analyzed from the content Analysis proposed by Bardin that constitutes systematic procedures of description lines of subjects surveyed. This technique becomes very useful to observe the processes of communication in various contexts, as well as to get an understanding of the meanings of the discussions at a level that goes beyond a common reading. ${ }^{19}$

The phases of this analysis technique applied to work initially included a transcription of the responses found; then sued the Constitution and organization of material and reading achievement for the definition of registry units that were used by the researchers, the encoding of the data obtained by transforming the raw data through aggregations (choice of categories) in order to achieve a representation of the content, or your expression, susceptible to clarify the characteristics of the data collected; distribution of components of the parsed data into categories, sorting them by differentiation and by restructuring around criterion or not previously established. ${ }^{19}$

From the analysis of the lines of workshop participants, elaboration of the following categories: concept of subject, subject and listening to and caring for caregivers. As regards the ethical aspects, the work followed the norms established for development to research with human beings, based on resolution 196/96 of the National Health Council, the project was submitted and approved by the Research Ethics Committee (CEP) of the Universidade Estadual do Ceará-UECE, with the number of approval: 083501630.This research was the Fundação Cearense for funded research support-FUNCAP. Public notice PPSUS-Research Program for the SUS.

\section{RESULTS AND DISCUSSION}

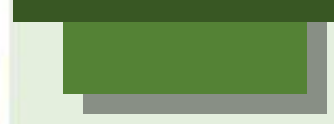

IN WHAT SUBJECT MATTER?

The first category refers to discussion of the participants of the research on the design that they have about subject. The nurses have expressed so heterogeneous, the understanding of subject in three perspectives: subject of the experiment, subject of the action, subject of language. The first perception can seized when the nurses try to associate the word subject to the qualities of the human being. This quality refers to a subject that is, experience is experience and he is made of subjectivities (...) “(Enf. 2). 
Here emerges the perception about the uniqueness of the subject, drawn from their experiences, their way of life, a relentless production that happens from the meetings that you live with the people who surround them.4 other participant full yet "is a story, a construction and he builds his subjectivity, his experience" (Enf. 3).

The second nurses ' perception, subject of the action, refers to the correlation of subject as an individual, active person, able to establish solutions to the decisions that are made, subject of his action, breaking with the situation of subject-object of mental health practices:

When talk about subject comes to me two things: the subject that part of the sentence, the prayer which is who acts who does the action and subject also of not being subjected to something else, not to be subject to something else, then, subject is one who acts (Enf. 1).

Subject of reason, owner of your choices (...) (Enf. 8).

The two perceptions of the subject above mark the understanding that the subject is not ready, but is on the data of experience, in contact with the events. We realize that most nurses leave to dwell about subjectivity, these relate to elements difficult to highlight in the care to patients in distress. The nurse 8 says, "We're not trained to understand the other in its subjectivity and, it is difficult to put into practice". Thus, we observe that the conception of subject addressed by nurses is approaching individual consistent, organized, subject of the action and which follows the Cartesian cogito.

This is still a perception that guides the practices of nurses in the care of patients with psychic suffering, conditioned by the prescriptive actions, has a character clearly adaptive and goal, a centralized clinic in giving "corrective" measures like the hygienic and feeding, behavior patterns, uses of drugs that, supposedly, placate suffering, putting makeup on the symptoms with anti-anxiety drugs or antidepressants. ${ }^{3}$

(...) It is not just this matter of subject, subject-object, but subject of language, the subject itself has a Division [conscious and unconscious] him between what he thinks he wants and what he does and what he does not know why, but it makes (Enf. 5).

This perception refers to the design of the subject of the unconscious. Relevant to nurses who work in the area of mental health, because the unconscious is the discourse of the Other, that is, the unconscious is in those words that come from somewhere else other than the speech I, IE, the unconscious is full of talk, the conversations, the goals, aspirations and fantasies of others. ${ }^{20}$

Thus, nurses can view the prospect of attending a patient in distress is not only to identify their basic human needs. To understand the unconscious like language, one realizes that the subject is in the world through what cannot be satisfied by demand understood in strictly biological sense, which guarantees the maintenance of life itself (hunger, cold, physical discomfort, etc.). The subject unconscious moved by something he always seeks to 
satisfy a craving and cannot find. Endless, lonely walk, the guy don't know what demand and which necessarily wants to find. ${ }^{9}$

By this argument, the answer of one of the nurses came as kick to problematize the discussion on the subject and listening to the patients in distress.

\section{SUBJECT and LISTEN}

The second category of subject analysis and listening refers the difficulty that nurses have to log the procedure relating to mental health in subject:

The procedure relating to mental health performed as if the listener was a routine. Questions ready. An everyday thing, but what you do is a conversation in the form of screening (Enf. 1).

We believe that change this approach implies going beyond the screening, the ability to listen without tying up the protocols, the condition of not having time, or even having their own desired time refers not to the assumption that the procedure relating to mental health is Fundação of your practice. Another speaks of $m$ nurse addresses this reality, regardless of the performance space:

Once arrived in CAPS a user who referred to the PSF CAPS because he was not able to sleep. When he got there, he said no, I am not able to sleep because my nose is stuffy. Because there (PSF) just heard this, he was not able to sleep and forwarded to the CAPS. In addition, suddenly there where there should be room to hear, often do not listen too (Enf. 8).

It refers to the difficulty that health professionals, regardless of their category and the practice scenario, have for completing the procedure relating to mental health. Don't listen, because, in the vast majority, the fact that the user talk for longer is synonymous with work overload, if the professional demand more time to hear this doesn't mean for the quality of care, but a waste of time, i.e. minutes wasted to develop other industrial activities. It is preferred therefore hear superficially listening. This reality also is present in the activities of the nurses in CAPS; post sorting words and time refer to objectivity, mechanicalness of Act of listening:

The professionals end up having no time for that [the patient] (...). What we do is just triage, know what he [patient] is, what symptoms feel (Enf. 6).

That way, we understand that taking care of Nursing Clinical patients in distress it is necessary that the nurse can go beyond screening, the ability to listen without tying up the protocols, the condition of not having time, or have your own desired time, refers to the assumption that the procedure relating to mental health is Fundação of your practice. We must adopt a new posture based on ethical dimension. 
In this perspective, the procedure relating to mental health becomes a strategy for the development of clinical nursing care, focusing on accountability in the process of the subject as it clarifies that each possesses in itself the answers to their problems. The nurse should peel off the professional position that already have the answer ready for the patient's problems, resigning in a few moments the talks, the justification, the desire to explain, persuade and respond the suffering of another.

In this context, the listener is important tool, because the unconscious structured like a language. Thus, a single via can only achieve the access to this structure, the patient's speech is through her that the subject will appear as language effect, unique effect, unique in every man. This effect says about the logic of a chain of signifiers that is built for each one way, because the brands that each man carries are also restricted to their existence, to his suffering. ${ }^{20}$

In some lines of workshop participants nurses realizes that they seek, in most clinical calls, if inquire on that subject is that which presents itself, for as he says and repeat the same thing, which has joint with his life story.

Has the patient gets there and tells the same story, since it is there, you already know about "co-salteado". However, that counts for each patient has a [professional] different story. We stay like that, huh, like listening. (Enf. 4).

The subject with significant joint effect is the subject of unconscious thought that language shaped structure. So the subject for psychoanalysis is an empty hollow structure the man does not so much as come-to-be, but how to be missing is a saying what he thinks, knowing what it says, i.e. what you know, but you do not know that you want to ignore. So, how to seize this guy who has no substance? Listening to what?

Is the Word as a means of access by the unknown subject in itself and the time of listening that underscores the uniqueness of senses of the word-referred to ${ }^{21}$ Words that unfold and ensure; that produce first and then discharges associations. Words that demonstrate the existence of another, but which also provide means of contact with the outside world when qualified in your listening. Listening for a body that speaks. ${ }^{22}$

A question that the procedure relating to mental health is not just information, you need to let the person talk several times until she can give a meaning to this right, and we see this in CAPS, patient talk, talk. And the symptom you articulate the history of life, is in the Act of speaking that he can solve the other treatment to this symptom, which is not just listen, listen and inquire for himself (Enf. 5).

What is more important in this speech is the significant that permeate and repeat themselves. The subject with significant joint effect is the subject of unconscious thought that language shaped structure. Is the Word as a means of access by the unknown subject in itself and the time of listening that underscores the uniqueness of senses of the wordreferred? ${ }^{9}$ Words that unfold and ensure; that produce first and then discharges associations. Words that demonstrate the existence of another, but which also provide 
means of contact with the outside world when qualified in your listening. Listening for a body that speaks. ${ }^{22}$ the nurse 5 covers:

(...) you have to let the person talk several times until she can give a meaning to this right (...) Is in the Act of speaking that he can solve the other treatment to this symptom, which is not just listen, listen and inquire for himself.

Freud $^{23}$ at $17 \mathrm{TH}$ Conference, the paths of the symptom shows that psychoanalysis, unlike Psychiatry, values, firstly, that the symptoms have a meaning and relate to the experiences, history of the patient's life. The symptom is carrying a message and it is not there by chance. He intrinsically related to the symbolic constructions of the subject. This way you need to listen to each subject and your relationship with your symptom. As follows the line:

He can speak a thousand times, but every time he speaks is of a different way then he's speaking, he's talking about and it's like he's rectifying it in his head, there will [break] let him speak because going to structuring the puzzle (Enf. 6).

You need to let the guy talk about his form, and know to expect Word by Word, without work, without be worried because he shut up for long minutes, or the nuances, the scores of the phrase. When this person speaks is that he can point to something their psychic reality. Sometimes it takes the subject talk about several other things or even about the same thing, until I can get to the ' $X$ ' of your question. ${ }^{24}$ We can perceive this reality from an example given by a nurse:

There is already another patient who is exactly the opposite, everyone who arrives she tells the same news. If she arrives at the gate, she says doctor I want to talk to you. This week she thinks she is pregnant and she is HIV positive. (...) Another person arrives, doctor come here, and I am going to tell you a secret. Moreover, any professional who arrives she tells the same secret, then when there in the living room, and broad question you already know the secret? I Know. Ask someone else. (...) She takes all the professionals to tell the secret (Enf. 6).

Even that language is our tool of access to the world, it is impossible for the subject represent everything. Something always escapes the possibility of representation, to appoint the experience. When this happens, we say that we are at the level of the traumatic anguish. The symptom appears to be trying to repair a crack that opens. In addition, thus, the subject can try reformulating others significant to their distress, anxiety and symptoms. ${ }^{25}$ 
I was at a screening; a woman said she had had a heartbreak. In addition, said: it broke my heart, and I fell in love with drugs, I have substituted the passion I had for the drug, so I cannot turn me off the drug (Enf. 8).

With this in mind, work with the listen tool acquires another meaning. It is not a question of gathering information about the patient to be able to speak about him, nor some sort of counseling where the nurse will instruct the patient about what happens to her. The listener becomes a privileged space where it may be possible to the emergency of the desire of this subject. ${ }^{3}$

As well as patient-side calls that say everything that comes into your mind without censoring the content side of the listener, requires floating attention, namely that the listener should not favor a priori any element of speech, because the subject is not one that knows what he's doing, but, on the contrary, that which accounts for what it does without knowing why. ${ }^{9}$ common phrases that can be perceived by the nurses in care to patients: "use the drug to forget my pain".

The clinical care mentioned by nurse eight elicited new correlations about what really sets up the complaint, symptom of the patient to seek the services of CAPS: is always the complaint about the use of illicit substance? What is the relationship of this subject with this drug and because it becomes a symptom to the subject? Why consider drugs as his new love? In this perspective, the attention by the floating nurse is essential, allowing professional capture what about what the subject says. Avoid trials, moralism.

This mode gives clinic to make space for the subject to draw up the specifics of his relationship with the other, which evidenced by his sayings or sayings. ${ }^{14}$. Thus, interventions through the basic tool of listening will be possible from attention subtext of speech what not expressed in words, the symptoms. Otherwise, fall again under biomedical model interview that part of prior knowledge absolute that puts the patient on condition object and not subject. ${ }^{4}$

The psychic apparatus refuses to get rid of an object that has already brought you pleasure a day. There is every moment, in the absence of the object, the subject reinvest anemic traits, i.e. traces of memories left by previous experiences, in order to achieve again the pleasure obtained. Thus, we see that the psychic apparatus works in a compulsion to repetition in search of the lost satisfaction. ${ }^{26}$ Sometimes, listening to a professional serves to point the fixing points of the subject, namely, the point to which the subject always returns and repeats. Freud $^{27}$, in his text remembering, repeating and elaborating brings the analysis process serves so that the subject can remember these anemic traits, repeating its shape and relationship with them and with the objects of pleasure and elaborate, i.e. understand why he does what he does it the way you do. CITES-if one speaks of another nurse participant:

She was on the bus coming home from work and very tired, she came with the eye closed. In addition, a man stood next to her and said give me alms. Moreover, she really tired I did not open the eye, put his hand in his pocket, pulled out a real and stretched him who said because boat here in my pocket. There she said she opened the eye fucking anger, but I am not saying make a real and still runs I put it in his pocket. The man had both 
arms, then she put the money in his pocket and went home, when he got home this woman simply no longer felt both her arms, then she was there in CAPS with a little ball of physical therapy, because they thought the problem was organic. So what explains to us this business? (Enf. 5).

It known that the medicine aims to transform the symptom, what is perceptible as change in the body, in significant meaning precisely the disease as being the truth immediately identifiable symptom. This establishment takes place through the intervention of an act that will effected by look and know doctor. In the account above, to change the sensitivity of the arms of the woman correlated to an organic injury thus making visible and stating the disease. Nothing better than trying to rehabilitate the body to work as before. ${ }^{1}$

For psychoanalysis, the symptom is also a significant, though the meaning is not pathological. Is also a sign, but not a sign that seize a character of disease? The symptom with significant for psychoanalysis has a sexual meaning, and as a sign, the symptom is a sign of the subject that something or anything he desires, but this desire must be regarded as inconceivable. However, even being an unwanted symptom desire is not completely hidden. ${ }^{25}$ He opens rift, walks the labyrinth and seeks escape anyway. Yes, the symptom, as well as in other formations of the unconscious, there is also a fulfillment of desire. ${ }^{1}$ in the interim, it is necessary to listen to better understand what and how the woman on the bus means the facts of his life. If she's being attended to in CAPS which the actions of the nurse with the distress this person? Which object of nursing clinical practice in mental health?

The symptom for psychoanalysis is a way to presentificar a desire that cannot said knowingly, i.e. something that satisfies the symptom, although conscious plan that experienced as suffering or dissatisfaction. That is why he should not see as something to be "eliminated" because it is an attempt to organize the subject their psychic reality. This does not mean that the subject did not suffer with this symptom. Nevertheless, it is through speech, articulation of signifiers that can undo the symptom, because the subject may symbolize these unspeakable things and seek a way out even better to elaborate their internal conflict ${ }^{1}$

Finally, listen to evoke client's speech means, what he says and why it says. It is considered the subject unaware that behind a demand that he himself is unaware of, in addition to the biological dimension. However, the listener process only has meaning because it allows you to count and count yourself, create and recreate a sense for who to talk to, so the person eases your anxiety simply by talking. This speech must necessarily pass through the other, i.e. it takes always another to say. If the other is not there, there is an absence. Thus, listening for it passes through the fact of listened to by the other. ${ }^{28}$

\section{LISTENING TO WHO CARES}

The third category may submitted from a single quest: one who listens too need not heard. The speech of participants of workshop permits reflect, from the perspective of psychoanalysis, about the pain of mind-ERS who operate in the Centre of psychosocial care (CAPS). As follows the line below: 
(...) Being that we all have our conflicts and we all have concerns, have time for us, as well, but "wait" what I'm doing, why I'm following this path here? (Enf. 4).

Currently, in the area of Mental health, it is recommended that health care professionals have unique characteristics that can enhance and, or "qualify" the production of the care Act, which assigns the nurse skills to know the signs and symptoms of pathological frames, thorough attention, understanding users. And if show subject weakened, if were to be inadequate for the exercise of their activities with patients in distress. $^{29}$

The abovementioned quest of the end reveals the need for mental health professionals to build a shield. Armored shield deviations, abnormalities, ensuring that these professionals remain exempt and, above all, sober in the face of reality. Armor that is capable, also, not to transpose to himself his own vulnerability and not (re) discover their own "conflicts". The work of nurses in mental health is regarded by participants as exhausting as a result of this present "adverse" situations as, for example, deal with the distress of other people, immersed in a world of hallucinations, aggression has its uses, suicidal thoughts and the everyday experience of situations that are repulsive to some people, stressful and terrifying. Perception demonstrated in the speech below:

Here is heavy. Every other week, we have an outbreak, we have a round [police] entering here, we have a patient by cutting or wanting to kill yourself or else a patient wanting to kill each other, (...) (Enf. 3).

And for me it's too bad, because that way, I get something that bad to me, because in addition to working here in CAPS, I still work on SAMU, just see something bad (Enf. 4).

The work, in the psychoanalytic perspective, becomes one of the possibilities found by man to live in society, more than this; it has been in the job a means of personal fulfilment in that it offers the man a chance to achieve the satisfaction of their impulses, even if indirectly, sublimated. The satisfaction never occurs in its fullness, but always partially restricted, and sudden. ${ }^{30}$

The work, then, is not restricted to the mere performance of the technical performance of the nurse in CAPS, but assumes acquisition emotional and therefore unaware that investment libidinal permeates their relations. In addition, when these impulses at work are not satisfied, or you did not find a way to sublimated by the subject, as by means of scientific, artistic and industrial productions, brings suffering to nurses who often manifests itself in symptoms. ${ }^{25}$ the work becomes a source of displeasure and pain. Moreover, in most cases the solution found by the nurses is to isolate the work, make-up their own symptoms with medications, trying to escape from suffering. Keep it down it turns out that this fact is something quite common in the reality of participants: 
How many people [professionals] we don't know enough to get license for not supporting the day to day CAPS as many people do, you have to get away from work, by not being able to cope with the distress of others and with her also (Enf. 5).

And for me it's too bad, because that way, I get something that bad to me, because in addition to working here, I still work on SAMU, just see something bad(Enf. 4).

In this way, the job can be a way of obtaining satisfaction of a wish, when allows the individual to keep his personal history articulated with social reality. However, the work does not eliminate the sufferings occasioned by the insertion in the civilized world. In fact, the object of desire is a missing object, which personified as lack of a pleasure that has already tried and looking to conducted through surrogates throughout life. Such replacement mechanism is in labor activities. This site allows the subject to enter the cultural world and mingle with other people-place of encounter between the desire and the anguish. That is, the search for the experience of satisfaction and absence of suffering. ${ }^{31}$

To assume that in practice in mental health this dealing with the size of the subject and its symptom, it is necessary that the nurses of the CAPS may, in addition to taking care of others, recognize that they are also subject to desires, that need to host your own symptoms, and give possibility that they are told.

Therefore, how to consider the therapeutic listening as a tool of work if there is no room for nurses listened. Yes, an important Foundation for therapeutic listening to with patients is the nurse know differentiate me on the other, because it is important that, one who listens, has passed also through a process of analysis, so you can know-how with Miss, with its empty, preventing the subjectivity, the anguish, the fear and the implications involved in the therapeutic process to meld. Know how to handle his own emptiness inside him. ${ }^{3}$ The lines following discuss the prospect of hearing and heard:

Just as well, so we all have our conflicts, how to deal with these people if we already have our conflicts, how to handle these people that way "(Enf. 3).

As it is, then how do we deal with the suffering whole, if we are talking about the subject has to be listened to and how do we deal with this suffering, without having a place where we can talk (Enf. 5).

It understood that the distress coupled to the ignorance of each other, their history, their unconscious desires and fantasies, when you are looking for a form of manifest. The only possible route is through the body in the form of symptoms. In addition, the symptom is the making of desire that manifests itself in its impossibilities. ${ }^{14}$ how to realize in the talks of one of the nurses:

The other nurse where I work say I need to talk to you. Therefore, I went to talk to the boy, Rui started to cry. Rui what is going on, all having a problem? Carlinda is not what I am; I am feeling so bad, because I cannot 
get past the life of the people. However, she went into a depressive state that needed medication. The Rui took over a month medicine (Enf. 7).

Therefore, it is necessary that nurses may also have a place where to forward their concerns. Is the speech mechanism that will allow nurses from CAPS to take care of your suffering for, later, at the meeting with patient, do emerge from the talks the subject of desire as subject inserted in the laws of language?

\section{CONCLUSION}

The preparation of this workshop allowed us to realize that the patient in distress not placed as subject of his practice. For this new attitude, clinical nursing care based on look, will only be possible if the nurse make a shift in its positioning front to those who attend, leaving the place of holding the "learn about the other" to a position that allows the other emerge as subject, unconscious. It is believed that psychoanalysis is a theoretical tool that can assist the nurse in this endeavor, as it forges a listening space that sustains an "ethic of desire", whose knowledge is supposed to be the person who speaks. It is considered the subject unaware that behind a demand that he himself is unaware of, in addition to the biological dimension.

The workshop allowed the nurses that the procedure relating to mental health could become a therapeutic tool, directed to issues that are of the subject, subject unconscious. Discuss on the importance of analyzing how each subject means the facts of her life, breaking with a clinical practice based on advice, to eliminate or mask the symptom through the medicalization. Thus, psychoanalysis may become an important theoretical framework for the practice of nurses in mental health services, based on listening to the subject, and in listening to the disease.

This work therefore passes by the possibility that the nurse, in exercise of activities where the encounter with the other is the increased focus, can open up space for the manifestation of the unconscious. This device allows the subject to emerge in stumbling conscious intentions of the one who speaks, can be recognized as such by the speaker. Furthermore, from that recognition opens space for the emergence of the new, because the subject has taken to admit, as it is a production that did not know, but that, nonetheless, does his part ${ }^{32}$.

Thus, it has a real "clinic of the subject" the important thing is exactly what the collective escapes, namely, the care of the singularity. This does not correspond to a segregation, as some may think. Yes, take care of uniqueness is to respect the principle of difference, of subjectivity ${ }^{33}$. Yes, we realize that by talks about the nurses who participated in the workshop, the lack of a theoretical framework that guided their actions and that enhances the size of subject structured in language, little specialized training in the area, 
difficult to delimit the work focus. Another point noted was the non-utilization of listening on the part of nurses as a therapeutic tool. The nurses that have cited the use of listening and working instruments referred to a superficial listening, as a synonym to hear and impose their knowledge.

Taking into account this reading of the unconscious and symptom in the development of mental health nursing practice requires the construction of strategies and techniques different from those transiting only in terms of consciousness. If not for the nurse play role of analyst, for being an unconscious process, who knows, can he make the experience of simply listening to the patient in their most diverse expressions: suffering, anguish, pain, in his successful achievements, failures, stumbling, among others? Moreover, not stick only to a form. 


\section{REFERENCES}

1. Quinet, A. A descoberta do inconsciente: do desejo ao sintoma. Rio de Janeiro: Jorge Zahar, 2008.

2. Lopes, R G. Quem é o sujeito da psicanálise? Tempo Psicanalítico: v.40, n. 2, p.12-59, 2008.

3 Almeida, A N S de. CUIDADO CLÍNICO DE ENFERMAGEM EM SAÚDE MENTAL: contribuições da psicanálise para uma clínica do sujeito [Dissertação]. Fortaleza (CE): Mestrado em Cuidados Clínicos em Saúde, Universidade Estadual do Ceará, 2009.

4. Mansano, S R V. Sujeito, subjetividade e modos de subjetivação na contemporaneidade. Rev.Psicologia UNESP 2009, dez/jan; 8(2):110-17.

5. Erlich, H. Psicanálise e ciência: um sujeito, dois discursos. [Dissertação]. Mestrado em Psicanálise. Universidade do Estado do Rio de Janeiro. Programa de Pós-Graduação em Psicanálise, 2007.

6. Lacan, J. (1966). A ciência e a verdade; In: LACAN, Jacques. Escritos. Tradução de Vera Ribeiro. Rio de Janeiro: Jorge Zahar, 1998. p. 855-92.

7. Alberti, S. Psicanálise e saúde mental: uma aposta. Rio de Janeiro: Companhia de Freud, 2006.

8. Lacan, J. (1956). A carta roubada. In: Lacan, J. Escritos. Rio de Janeiro: Jorge Zahar, 1998. p. 197 - 213.

9. Dor, J. Introdução à leitura de Lacan: o inconsciente estruturado como linguagem. Porto Alegre: Artes Médicas, 1989.

10. Birman, J. O sujeito no discurso freudiano. In: Estilo e modernidade em psicanálise. São Paulo: ed. 34, p. 15-42, 1997.

11. Brant, L C; Minayo-Gomez, C. Dispositivos de transformação do sofrimento em adoecimento numa empresa. Psicologia em Estudo 2007 set/dez; 12(3): 465-473.

12. Franco, T B; Magalhães, JR. Atenção Secundária e a Organização das Linhas de Cuidado. In: Merhy, E E et al. O Trabalho em Saúde: olhando e experienciando o SUS no cotidiano; São Paulo: HUCITEC, 2003.

13. Kirschbaum, D I R. O trabalho de Enfermagem e o Cuidado em Saúde Mental: novos rumos? Cad. do IPUB 2000 set/dez; 6(19):15-36.

14. Quinet, A. Os Outros em Lacan. Rio de Janeiro: Zahar, 2012.

15. Poujol, J. Manual de relacionamento de ajuda conselhos práticos para acompanhamento psicológico e espiritual. Tradução: Norma Cristina Guimarães Braga. São Paulo: Vida Nova, 2006.

16. Freud, S. (1905) Três ensaios sobre a teoria da sexualidade. In: Freud, S. Edição Standart Brasileira das Obras Completas de Sigmund Freud. Rio de Janeiro: Imago, v. 7, 1996. 
17. Minayo, M C S. (org.).Pesquisa social: teoria, método e criatividade. 6 ed. Petrópolis : Vozes, 1996.

18. Marcon, H H. A subjetividade no trabalho com saúde mental. Psyche 2007 jun;11(20):151-164.

19. Bardin, L. Análise de conteúdo. Lisboa/Portugal: Edições 70, 2008.

20. Lacan, J. (1956 ). A instância da letra no inconsciente ou a razão desde de Freud. In: Lacan J. Escritos. Rio de Janeiro: Jorge Zahar; 1998. p. 496-533.

21. Lacan, J (1957-1958). O seminário livro 5: as formações do inconsciente. Rio de Janeiro: Jorge Zahar; 1999.

22. Macedo, M M K; Falcão, C. N. de B. A escuta na psicanálise e a psicanálise da escuta. Revista Psyche 2005 jan/jun; 9(15):65-76.

23. Freud, S. (1916-1917). Conferência XVII: O sentido dos sintomas. In: Freud, S. Obras Psicológicas Completas de Sigmund Freud. Trad. José Octávio de Aguiar Abreu. Rio de Janeiro: Imago, v. 16, 1996.

24. Freud, S. (1913). Sobre o início do tratamento. In: Freud, S. Edição Standart Brasileira das Obras Completas de Sigmund Freud. Trad. José Octávio de Aguiar Abreu. Rio de Janeiro: Imago, v.2 1996.

25. DIAS, M G L V. O sintoma: de Freud a Lacan. Psicologia em Estudo 2006 mai/ago; 11(2): 399-405.

26. Freud, S. (1920). Além do princípio de prazer. In: Freud, S. Edição Standart Brasileira das Obras Completas de Sigmund Freud. Trad. José Octávio de Aguiar Abreu Rio de Janeiro: Imago, v.18, 1987.

27. Freud, S. (1914). Recordar, Repetir e Elaborar In: Freud, S. Edição Standart Brasileira das Obras Completas de Sigmund Freud. Trad. José Octávio de Aguiar Abreu. Rio de Janeiro: Imago, v. 16, 1996.

28. Poujol, J. Manual de relacionamento de ajuda conselhos práticos para acompanhamento psicológico e espiritual. Tradução: Norma Cristina Guimarães Braga. São Paulo: Vida Nova, 2006.

29. Borsoi, I C F. Da relação entre trabalho e saúde à relação entre trabalho e saúde mental. Psicologia e Sociedade 2007 mar;19(1):103 -11.

30. Mendes, A M B;Tamayo, A. Valores organizacionais e prazer-sofrimento no trabalho. Rev. Psico USF 2001 jan/jun; 6(1):36-49.

31. Bertão, F R B M; Hashimoto, F. Entre o desejo e o sofrimento psíquico no trabalho: um estudo de caso com professora de educação infantil. Psicologia em revista 2006 dez;12(20):141-163.

32. Elia, L O conceito de sujeito. Rio de Janeiro: Jorge Zahar, 2004.

33. Assad, M M E et al. Algumas contribuições da psicanálise ao campo da saúde mental. Rev. Conceitos 2004 dez; 11 (esp): 45-57. 